\title{
A new species of Hyphessobrycon Durbin (Characiformes: Characidae) from the middle rio São Francisco and upper and middle rio Tocantins basins, Brazil, with comments on its biogeographic history
}

\author{
Fernando C. P. Dagosta ${ }^{1}$, Manoela M. F. Marinho ${ }^{1,2}$ and Priscila Camelier ${ }^{1}$
}

A new species of Hyphessobrycon Durbin is described from tributaries of the rio Grande (rio São Francisco basin) draining east to the Serra Geral de Goiás, of the rio São Domingos (upper rio Tocantins basin) and rio do Sono basins (middle rio Tocantins basin). Hyphessobrycon diastatos can be diagnosed from its congeners by the absence of humeral spot, 15-18 branched analfin rays, 1-3 maxillary conical to tricuspid teeth, a relatively well-defined dark caudal-peduncle spot, and elongation of dorsaland anal-fin rays in mature males. The biogeographical significance of the distribution of the new species is evaluated and discussed.

Uma espécie nova de Hyphessobrycon Durbin é descrita dos tributários do rio Grande (bacia do rio São Francisco) que drenam a leste a Serra Geral de Goiás, das bacias dos rios São Domingos (bacia do alto rio Tocantins) e rio do Sono (bacia do médio rio Tocantins). Hyphessobrycon diastatos pode ser diagnosticada de seus congêneres pela ausência de mancha umeral, 15-18 raios ramificados na nadadeira anal, 1-3 dentes maxilares cônicos ou tricuspidados, uma mancha escura relativamente bem definida no pedúnculo caudal e alongamento das nadadeiras dorsal e anal em machos maduros. O significado biogeográfico da distribuição da espécie nova é avaliado e discutido.

Key words: Adipose fin, Biogeography, Headwater capture, Serra Geral de Goiás, Sexual dimorphism.

\section{Introduction}

Hyphessobrycon Durbin is one of the most species-rich genera of the Characidae, comprising approximately 130 valid species (Carvalho \& Langeani, 2013; García-Alzate et al., 2013a, 2013b; Ingenito et al., 2013). The genus is distributed from Southern Mexico to the rio de La Plata in Argentina, and most of its diversity occurs east of the Andes. Hyphessobrycon was proposed by Durbin in Eigenmann (1908) as a subgenus of Hemigrammus Gill, differing from the latter by the absence of scales covering the caudal-fin lobes. The two genera were revised by Eigenmann (1917) who raised Hyphessobrycon to full generic status. Eigenmann's accounts are still the single most comprehensive review of the group.

Attempts to define subgroups within Hyphessobrycon were based mainly on color patterns (e.g., Géry, 1966, 1977;
Weitzman \& Palmer, 1997; Ingenito et al., 2013), although the monophyly of such groups has never been tested. Several authors (e.g., Eigenmann, 1917; Weitzman \& Fink, 1983; Weitzman \& Palmer, 1997) commented about the potential nonmonophyletic nature of the genus, a supposition that has been confirmed in recent phylogenetic analyses (e.g., Javonillo et al., 2010; Mirande, 2009, 2010; Oliveira et al., 2011; Malabarba et al., 2012). Unfortunately, all such studies included only a small number of Hyphessobrycon species, not representative of the actual diversity of the genus, as a consequence, its limits and composition remain open to question.

During a recent expedition to upper and middle portions of the rio Tocantins and middle rio São Francisco, a new species of Hyphessobrycon was found to occur in part of the two basins. The new species is herein described and its particular biogeographical significance is discussed.

\footnotetext{
${ }^{1}$ Museu de Zoologia da Universidade de São Paulo. Avenida Nazaré, 481, Ipiranga, Caixa Postal 42494, 04218-970 São Paulo, SP, Brazil. ferdagosta@gmail.com,manumfm@yahoo.com.br, pricamelier@gmail.com

${ }^{2}$ UNESP, Universidade Estadual Paulista “Júlio de Mesquita Filho”, Instituto de Biociências, Letras e Ciências Exatas. Rua Cristóvão Colombo, 2265, Jardim Nazareth, 15054-000 São José do Rio Preto, SP, Brazil.
} 


\section{Material and Methods}

Counts and measurements follow Fink \& Weitzman (1974), except for number of horizontal scale rows below lateral line, which are counted to the pelvic-fin insertion, not including the small scale at pelvic-fin insertion, and with the addition of head depth, measured at vertical through the posterior end of supraoccipital spine and pelvic-fin origin to anal-fin origin measured at origin of pelvic-fin through the anal-fin origin. Standard length (SL) is expressed in millimeters ( $\mathrm{mm}$ ) and all other measurements are expressed as percentage of SL, except subunits of head, which are expressed as percentage of head length. Meristic data are given in the description, with the frequency of each count provided in parentheses after the respective count. An asterisk indicates counts of the holotype. Counts of maxillary tooth cusps, number and cusps of small dentary teeth, supraneurals, branchiostegal rays, gill rakers, vertebrae, and procurrent caudal-fin rays are taken from cleared and stained specimens (c\&s) prepared according to Taylor \& Van Dyke (1985). Vertebrae of the Weberian apparatus are counted as four elements and the compound caudal centra (PU1+U1) as a single element. The positive correlation between sex and fin elongation was confirmed on fourteen specimens, by direct examination of gonads. Color in life was described on the basis of photographs of five live specimens taken in the field. In specimen list, catalog numbers are followed by the number of specimens in alcohol, their SL range, and if any, the number of c\&s specimens and their respective SL range. Subdivisions of the rio Tocantins basin follow Ribeiro et al. (1995). Institutional abbreviations are: INPA, Instituto Nacional de Pesquisas da Amazônia, Manaus; FMNH, Field Museum of Natural History, Chicago; MCP, Museu de Ciências e Tecnologia, Pontifícia Universidade Católica do Rio Grande do Sul, Porto Alegre; MCZ, Museum of Comparative Zoology, Harvard University, Cambridge; MZUSP, Museu de Zoologia da Universidade de São Paulo, São Paulo; UFBA, Museu de Zoologia da Universidade Federal da Bahia, Salvador; ZMB, Museum für Naturkunde, Humboldt Universität, Berlin.

\section{Hyphessobrycon diastatos, new species}

Figs. 1-3

Hasemania sp. - Lima \& Caires, 2011: 235, 239, 243, and 248 (listed).

Hemigrammus sp. 2 “Sapão” - Lima \& Caires, 2011: 235, 241, 243, and 248 (listed).

Holotype. MZUSP 114030, 24.4 mm SL, Brazil, Bahia, São Desidério, rio Galheirão (or rio da Estiva) at BR-020 road, affluent of rio Grande, rio São Francisco basin, 1258’42.7"S 45⒌'28.7"W, 802 m above sea level, 4 Dec 2012, J. Birindelli, F. Dagosta, M. V. Loeb \& C. Santos.

Paratypes. All from Brazil. INPA 39960, 5, 18.8-20.9 mm SL; MCP 48060, 5, 18.7-22.2 mm SL, and MZUSP 114029, 41, 14.4-25.2 mm SL, same data as holotype. MZUSP 114026, 35, 10.3-22.3 mm SL, 2 c\&s, 19.2-29.9 mm SL, Bahia, Barreiras, rio das Balsas, bridge at BA-458 road, Luís Eduardo Magalhães to Cotia, affluent of rio Grande, rio São Francisco basin, 1159’34.5"S 45³4’49.2"W, 3 Dec 2012, J. L. O. Birindelli, F. Dagosta, M. V. Loeb \& C. Santos. MZUSP 40894, 62, 15.7-25.5 mm SL, Goiás, São Domingos, Riacho Curral de Pedra along GO-362 road, 3 km from São Domingos, affluent of rio São Domingos, rio Tocantins basin, 13²3'59"S 46¹8'59"W, 14 Jan 1989, J. C. Oliveira \& W. J. M. Costa. MZUSP 58586, 62, 19.2-27.9 mm SL, Goiás, São Domingos, stream affluent of rio São Domingos, at road to São Domingos, about $5 \mathrm{~km}$ of bifurcation on BR-020 road, rio Tocantins basin, 13¹9’23"S 4607’15"W, 10 Jul 1998, O. T. Oyakawa, A. Akama \& V. Garutti. MZUSP 98494, 16, 22.6-26.1 mm SL, Tocantins, Mateiros, rio Novo, near mouth of córrego Lajeiro, rio Tocantins basin, $10^{\circ} 46^{\prime 2} 23^{\prime \prime S}$ 4643’08"W, 1 Feb 2008, F. C. T. Lima, R. A. Caires \& C. Nogueira. MZUSP 98507, 1, 23.4 mm SL, Tocantins, Mateiros, rio Preto, North limit of Estação Ecológica Serra Geral do Tocantins, near Região das Dunas, rio Tocantins basin, 10³8'40"S 4641’02"W, 1 Feb 2008, F. C. T. Lima, R. A. Caires \& C. Nogueira. MZUSP 98531, 38, 11.8-17.6 mm SL, Bahia, Formosa do Rio Preto, Vereda do rio Sapão, rio São Francisco basin, 1044’41"S 46¹1’45"W, 3 Feb 2008, F. C. T. Lima, R. A. Caires \& C. Nogueira. MZUSP 109772, 1, 23.6 mm SL, Bahia, São Desidério, rio Galheirão (or rio da Estiva) at BR-020 road, affluent of rio Grande, rio São Francisco basin, 1258'S 4559’W, 17 Feb 2011, A. Akama \& J. L. O. Birindelli. MZUSP 114027, 10, 19.2-21.2 mm SL, Bahia, Luís Eduardo Magalhães, rio do Borá, affluent of rio das Ondas, affluent of rio Grande at BR-020, 12²17’58.9"S 4550’55.4"W, 4 Dec 2012, J. Birindelli, F. Dagosta, M. V. Loeb \& C. Santos. MZUSP 114031, 11, 18.9-26.7 mm SL, Goiás, São Domingos, rio São Domingos at road GO-463 to São Domingos, rio Tocantins basin, 13¹9'23"S 4607’15.2"W, 5 Dec 2012, J. L. O. Birindelli, F. Dagosta, M. V. Loeb \& C. Santos. MZUSP 114028, 4, 19.2-21.4 mm SL, Bahia, São Desidério, rio Pau de Óleo, affluent of rio das Fêmeas, affluent of rio Grande at BR-020 road, rio São Francisco basin, 1241’24.3"S 4555’48.9"W, 4 Dec 2012, J. L. O. Birindelli, F. Dagosta, M. V. Loeb \& C. Santos.

Diagnosis. Hyphessobrycon diastatos differs from all congeners, except $H$. amandae Géry \& Uj, H. axelrodi (Travassos), H. brumado Zanata \& Camelier, H. compressus (Meek), H. diancistrus Weitzman, H. eilyos Lima \& Moreira, H. georgettae Géry, H. heteresthes (Ulrey), H. gracilior Géry, $H$. milleri Durbin, H. minimus Durbin, H. negodagua Lima \& Gerhard, H. otrynus Benine \& Lopes, $H$. parvellus Ellis, $H$. piabinhas Fowler, $H$. procerus Mahnert \& Géry, H. saizi Géry, $H$. scutulatus Lucena, H. taurocephalus Ellis, and H. tukunai Géry by the absence of any concentration of chromatophores at the humeral region (vs. presence of a dark humeral spot or/ and a longitudinal dark stripe extending over the humeral region). The new species can be diagnosed from $H$. otrynus, $H$. piabinhas, and $H$. procerus by having $15-18$ branched anal-fin rays (vs. 19 or more); from H. amandae, H. axelrodi, $H$. compressus, $H$. georgettae, $H$. heteresthes, and H. milleri by the absence of a dark blotch in the dorsal fin (vs. presence); from $H$. eilyos and $H$. scutulatus by having 1-3 maxillary teeth (vs. 5 or more); from H. diancistrus by having hyaline caudalfin lobes (vs. caudal lobes with a black spot); from $H$. gracilior 


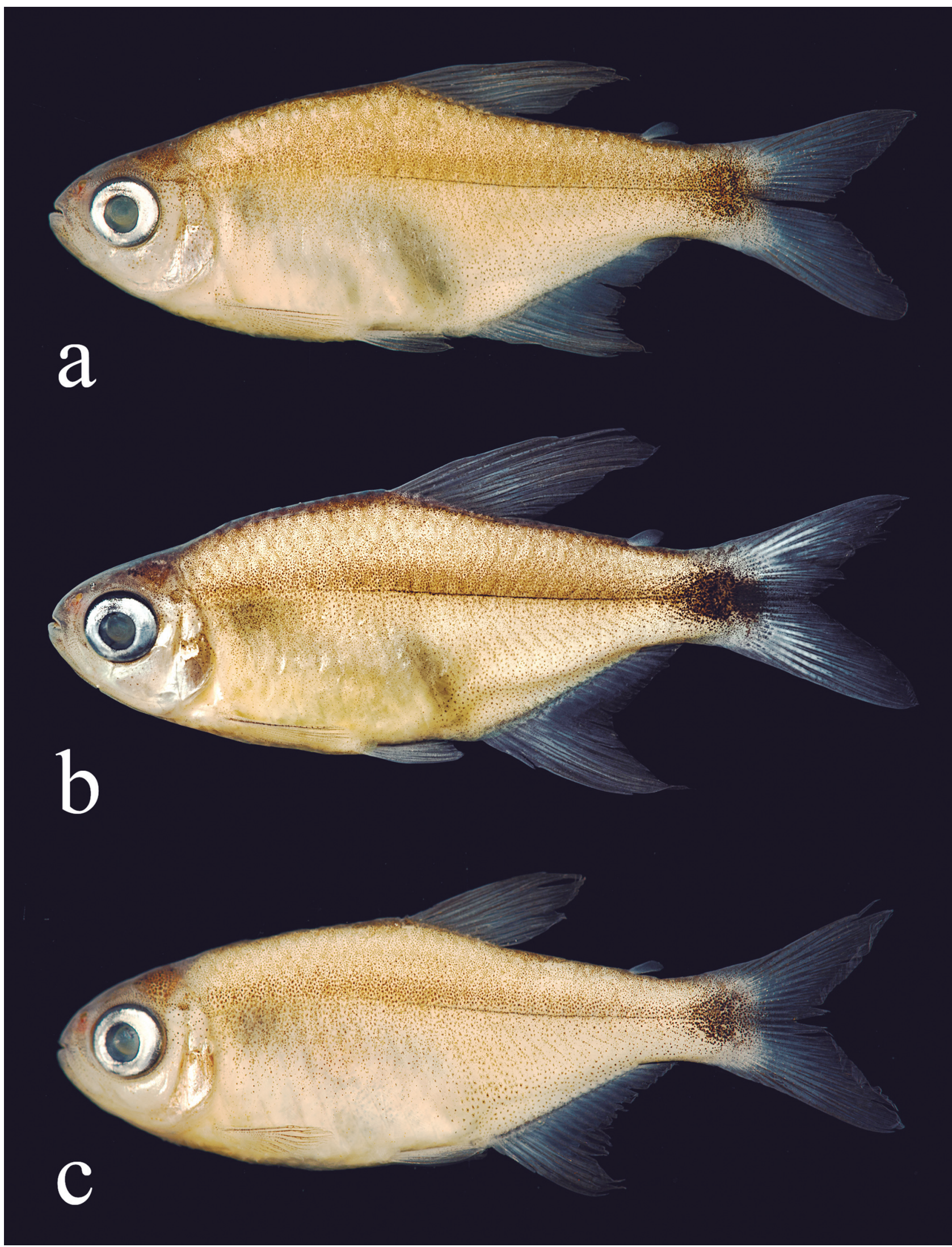

Fig. 1. Hyphessobrycon diastatos, all from Brazil, Bahia, São Desidério, rio Galheirão (or rio da Estiva), affluent of rio Grande, rio São Francisco basin, (a) holotype, MZUSP 114030, 24.4 mm SL, male, (b) paratype, MZUSP 114029, 25.2 mm SL, male, and (c) paratype, MZUSP 114029, 20.8 mm SL, female. 
by the presence of 4-5 longitudinal scale rows below the lateral line (vs. 3); from H. minimus by having the largest dentary teeth with 3-5 cusps (vs. 7); from $H$. saizi by having 14 horizontal scale rows around caudal peduncle (vs. 12) and 1012 predorsal scales (vs. 9); from $H$. taurocephalus by having adipose fin (rarely absent, 1 of 294 specimens) and 15-18 branched anal-fin rays (vs. adipose fin absent and 12-15); and from $H$. tukunai by having 2-5 teeth in the outer premaxillary teeth row (vs. 1, rarely 2), besides the maxillary teeth with 1-3 cusps (vs. 5 or more). It can be distinguished from H. brumado, $H$. negodagua, and $H$. parvellus by the round and relatively well-defined dark caudal-peduncle spot in males (vs. caudalpeduncle blotch with inconspicuous border in males, frequently only represented by dense pigmentation on this region) and also by the absence of white pigmentation on distal portions of first rays of dorsal, anal, and caudal fins in life (vs. presence). The new species is further distinguished from $H$. negodagua and $H$. parvellus by having dark pigmentation of caudal-peduncle spot extending to base of few middle caudal-fin rays or reaching their tip, never on caudal lobes in males (vs. caudal-peduncle pigmentation spread from middle caudal-fin rays to inner portions of caudalfin lobes in males). Hyphessobrycon diastatos is further distinguished from $H$. brumado and $H$. parvellus by having pectoral, pelvic, and anal fins hyaline to slightly yellowish in life (vs. distinct orange- to reddish) and presence of sexually dimorphic elongation of dorsal and anal fins in males (vs. absence). It can be further diagnosed from $H$. brumado by the overall silvery body color in life (vs. orange- to reddish) and from $H$. negodagua by the absence of dense concentration of dark chromatophores over dorsum and posterior portion of body (vs. presence) and by the presence of adipose fin (rarely absent, 1 of 294 specimens) (vs. usually absent; 4 of 158 with adipose fin; see discussion for further details).

Description. Morphometric data in Table 1. Body compressed, moderately elongate. Greatest body depth slightly anterior to dorsal-fin origin. Dorsal profile of head convex from upper lip to vertical through anterior nostril; slightly convex from that point to tip of supraoccipital spine. Dorsal profile of body slightly convex along predorsal region, straight and posteroventrally inclined along dorsal-fin base, slightly convex from terminus of dorsal-fin base to adipose-fin origin, and concave to origin of anteriormost dorsal procurrent caudal-fin ray. Ventral profile of head and body convex from tip of lower lip to pelvic-fin origin, straight to slightly concave between latter point to origin of anal-fin origin, straight to slightly convex and posterodorsally inclined along anal-fin base, and concave to origin of anteriormost ventral procurrent caudal-fin ray.

Jaws equal, mouth terminal. Premaxillary teeth in two rows. Outer row with 2(3), 3(19), 4(7), or 5*(1) conical or tricuspid teeth. Inner row with $5^{*}(29)$ or 6(1) tri- to pentacuspid teeth. Posterior tip of maxilla at vertical through posterior half of second infraorbital. Maxilla with 1(18), 2*(11), or 3(1) conical or tricuspid teeth. Dentary with $3 *(30)$ larger teeth, medial tooth tri- to pentacuspid, lateral teeth tricuspid, followed by one smaller conical or tricuspid, and a series of 6(2) diminute conical teeth. Central median cusp in all teeth longer than lateral cusps. Branchiostegal rays 4(2). First gill arch with 1(1) or 2(1) gill rakers on hypobranchial, 7(1) or 8(1) rakers on ceratobranchial, 1(2) rakers on intermediate cartilage, and 4(1) or 5(1) rakers on epibranchial.

Scales cycloid, with 3-5 radii on posterior border, and conspicuous circulii anteriorly. Lateral line incomplete, with 5(1), 6(10), 7*(12), or 8(7) perforated scales, and 31(9), 32*(17), $33(2)$, or 34(2) scales on longitudinal series. Longitudinal scale rows between dorsal-fin origin and lateral line $5^{*}(24)$ or $6(6)$. Longitudinal scale rows between lateral line and pelvic-fin origin $4 *(22)$ or 5(8). Scales along middorsal line between tip of supraoccipital process and dorsal-fin origin $10(5), 11 *(19)$, or 12(6). Horizontal scale rows around caudal peduncle $14 *(30)$. Base of anteriormost anal-fin rays covered by a series of 4 or 5 scales. Caudal fin not scaled.

Supraneurals 4(1) or 5(1). Dorsal-fin rays ii*(27) or iii(3), $8(3)$ or $9 *(27)$. First dorsal-fin pterygiophore inserted posterior to neural spine of $10^{\text {th }}$ vertebra (2). Base of last dorsal-fin ray at vertical through base of first branched anal-fin ray. Pectoralfin rays $i^{*}(30), 9(8), 10(20)$, or $11 *(2)$. Pelvic-fin rays i,6*(30). Adipose fin of variable size, present in 294 specimens, absent in one individual (MZUSP 40894; Fig. 4). Anal-fin falcate, with iii(16) or iv*(14), 15(6), 16*(15), 17(8), or 18(1) branched rays. First anal-fin pterygiophore inserted posterior to haemal spine of $16^{\text {th }}$ (2) vertebra. Principal caudal-fin rays i,9/8,i*(30); caudal fin forked, lobes somewhat pointed, of similar size. Dorsal procurrent caudal-fin rays 9(2); ventral procurrent caudal-fin rays $5(1)$ or $7(1)$. Total vertebrae $31(1)$ or 32(1): precaudal vertebrae 14(1) or 15(1) and caudal vertebrae 17(2).

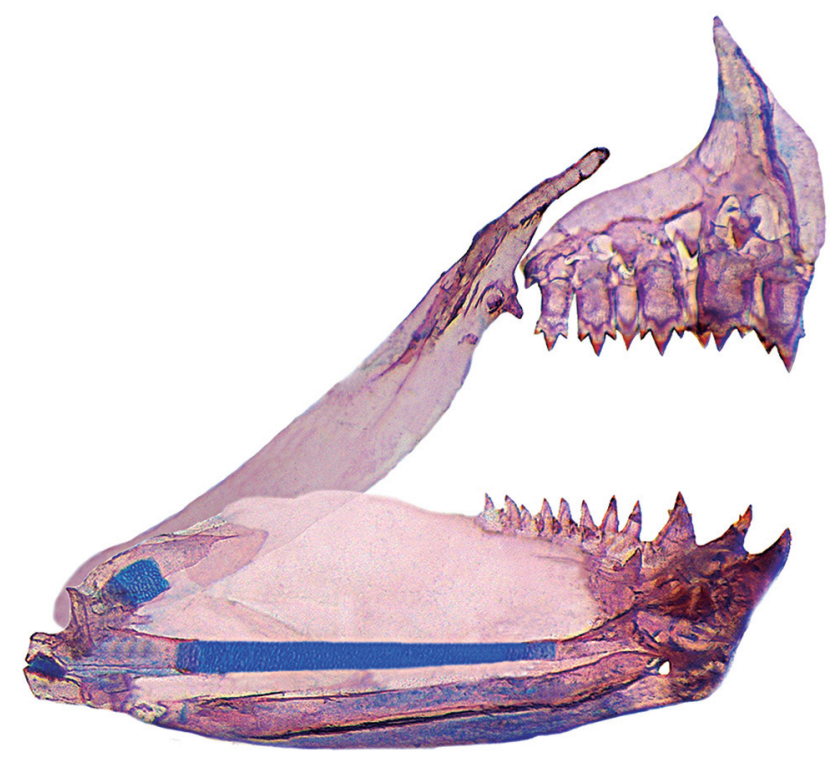

Fig. 2. Hyphessobrycon diastatos, paratype, MZUSP 114026, $19.2 \mathrm{~mm}$ SL; medial view of left side, upper and lower jaws. Part of Meckel's cartilage damaged was reconstituted using graphic software. Coronomeckelian is missing. 
Color in alcohol. Overall ground coloration pale (Fig. 1). Infraorbital, opercular, and gular areas retaining some guanine. Dorsal portion of head and body dark. Dark chromatophores concentrated at upper and lower jaws and upper portion of opercle. Upper and lower lips with a dark line. Some specimens with dark chromatophores scattered at infraorbital series. Humeral spot absent. A thin longitudinal line formed by embedded dark pigmentation along horizontal septum, approximately from vertical through pelvic-fin origin to caudal peduncle. No evident longitudinal stripe, some specimens from rio Tocantins basin with more intense concentration of chromatophores along the midlateral body line. Body pigmented by small dark chromatophores, more intense at its dorsolateral portion, fading ventrally. Some specimens with slight reticulated pattern on first two horizontal scale rows, formed by concentration of chromatophores on the posterior portion of scales. Abdominal region devoid of chromatophores. Distal portion of dorsal and anal fins with dark pigmentation on interadial membranes, more intense in males than in females (Figs. 1b- c, respectively). A well-defined black round spot extending from posterior half of caudal peduncle to base of middle caudal-fin rays (Figs. 1c; 6a, c), or reaching their tips (Figs. $1 \mathrm{a}, \mathrm{b} ; 6 \mathrm{~b})$. All fins with dark chromatophores along edge of lepidotrichia.

Color in life. Coloration in life similar to described above for preserved specimens, except for overall body coloration silver to yellowish. Infraorbitals, preopercle, and opercle silvery. Dorsal portion of iris yellow to orange. Pectoral, pelvic, and anal fins slightly yellowish to almost hyaline. Some specimens with distal portion of first anal-fin rays distinctly darker, especially males (Fig. 3a). Dorsal and adipose fins orange- to slightly yellowish. Conspicuous black blotch over caudal peduncle and median caudal-fin rays. Caudal fin orange- to slightly yellowish (Figs. 3a, b).

Sexual dimorphism. Mature males with dorsal (30.2-39.7\%, mean $=33.1 \%$ of SL) and anal fins $(22.5-34.6 \%$, mean $=26.4 \%$ of SL) longer than in females (24.7-31.3\%, mean $=28.0 \%, 19.0$ -

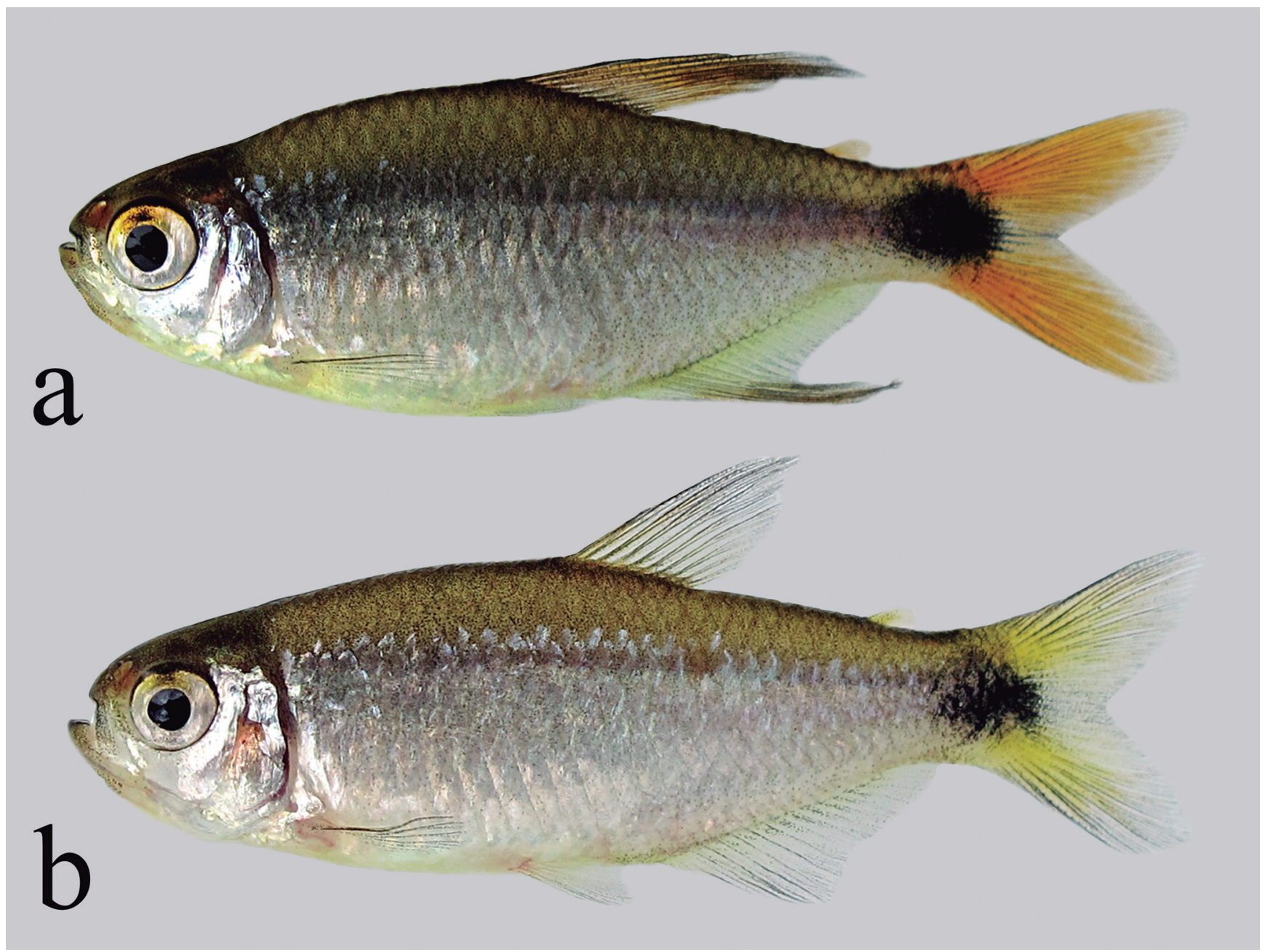

Fig. 3. Live coloration of Hyphessobrycon diastatos. (a) paratype, MZUSP 114029, 25.2 mm SL, male, Brazil, Bahia, São Desidério, rio Grande drainage, rio São Francisco basin, and (b) paratype, MZUSP114031, 26.7 mm SL, female, first anal-fin rays broken, Brazil, Goiás, São Domingos, rio São Domingos, rio Tocantins basin. 
$23.0 \%$, mean $=20.8 \%$ of SL, respectively) (Fig. 4). Bony hooks on fins were not found in any specimen analyzed. Based on the five photographed live specimens, two males and three females, it is possible that Hyphessobrycon diastatos presents sexual dimorphic coloration in life. Males have dorsal and caudal fins orange, and distal portion of first dorsal- and analfin rays dark (Fig. 3a). Females have slightly yellowish to almost hyaline fins (Fig 3b).

Geographic distribution. Hyphessobrycon diastatos is known from tributaries of the rio Grande (rio São Francisco basin) draining east to the Serra Geral de Goiás, from the rio São Domingos (upper rio Tocantins basin) and rio do Sono basins (middle rio Tocantins basin) (Fig. 5).

Etymology. The specific name diastatos comes from the Greek, meaning divided, in reference to its geographic distribution in both the rio São Francisco and the rio Tocantins basins.

Habitat and ecological notes. Hyphessobrycon diastatos was collected in clear water streams running over submerged vegetation and sandy bottom, at altitudes ranging from 430
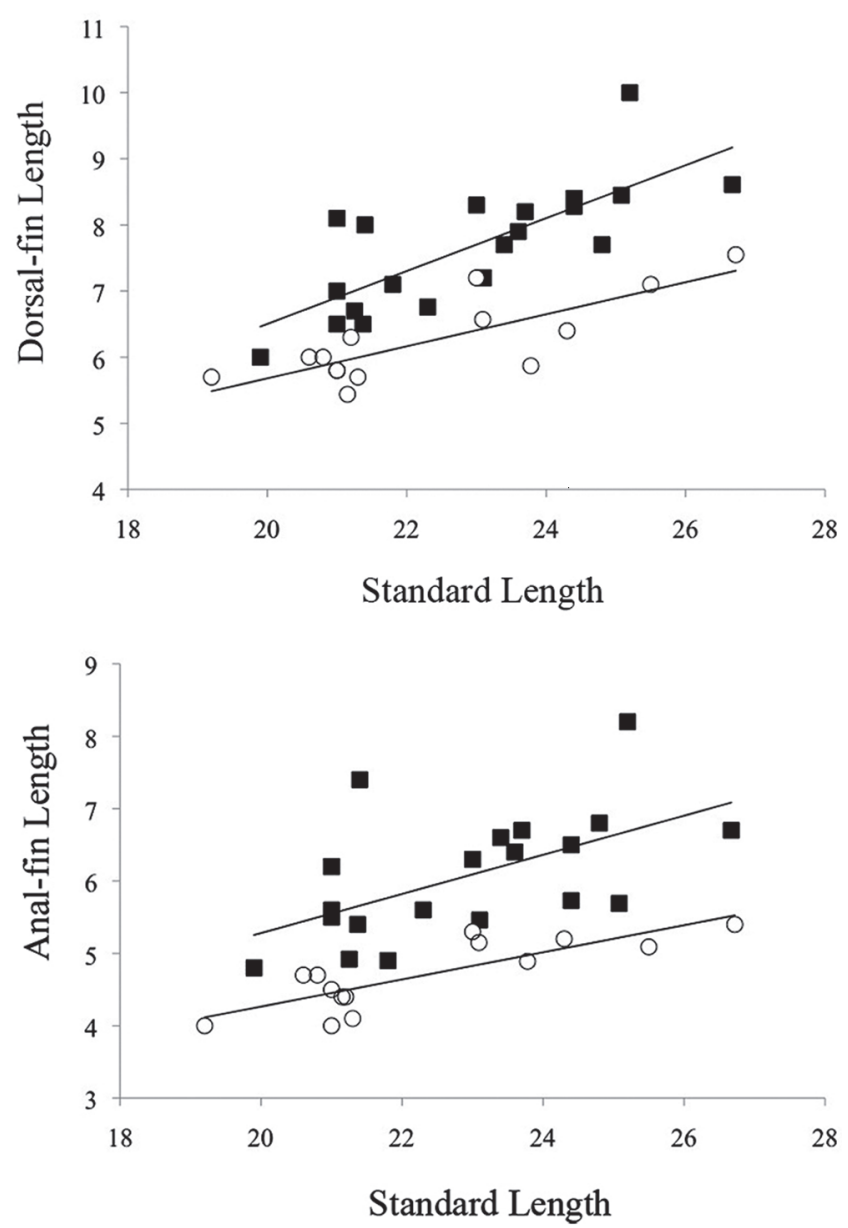

Fig. 4. Fin lengths as function of standard length by sex in males (black square, $n=20$ ) and females (white circle, $n=14$ ) of Hyphessobrycon diastatos, (a) dorsal fin, and (b) anal fin.

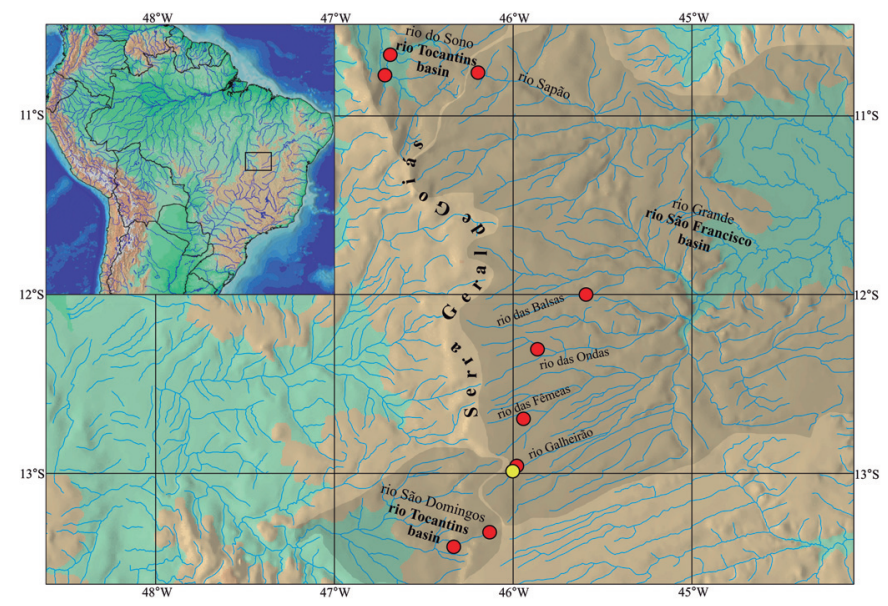

Fig. 5. Distribution of Hyphessobrycon diastatos in the middle rio São Francisco basin and upper and middle rio Tocantins basin, Brazil. Yellow dot represents the holotype and red dots the paratypes. Each dot may represent more than one collection event.

to $935 \mathrm{~m}$ above sea level, with relatively swift water current. The riparian vegetation is mainly composed of grass, herbs, and shrubs. Analysis of stomach contents of four specimens revealed the presence of allochthonous and autochthonous items, composed of fragments of plants, organic debris, insect larvae (Diptera and Trichoptera: Hydroptilidae), fragments of adults of terrestrial insects (Hymenoptera: Formicidae, Orthoptera, and unidentified orders) and of other unidentified

Table 1. Morphometric data of Hyphessobrycon diastatos. Range includes holotype. SD= Standard deviation.

\begin{tabular}{|c|c|c|c|c|c|}
\hline & Holotype & $\mathrm{n}$ & Range & Mean & SD \\
\hline Standard length (mm) & 24.4 & 36 & $19.2-26.7$ & 22.8 & - \\
\hline \multicolumn{6}{|l|}{ Percents of SL } \\
\hline Depth at dorsal-fin origin & 37.7 & 32 & $30.8-38.7$ & 35.1 & 2.1 \\
\hline Snout to dorsal-fin origin & 54.9 & 32 & $51.0-57.3$ & 55.2 & 1.3 \\
\hline Snout to pectoral-fin origin & 29.1 & 32 & $26.5-29.6$ & 27.9 & 0.9 \\
\hline Snout to pelvic-fin origin & 48.4 & 32 & $45.7-51.0$ & 49.3 & 1.3 \\
\hline Snout to anal-fin origin & 65.2 & 32 & $61.9-67.8$ & 65.3 & 1.3 \\
\hline Caudal-peduncle depth & 14.3 & 36 & $10.4-15.7$ & 13.0 & 1.1 \\
\hline Caudal-peduncle length & 12.3 & 32 & $10.8-14.1$ & 12.3 & 1.0 \\
\hline Pectoral-fin length & 19.3 & 32 & 18.1 & 19.8 & 1.1 \\
\hline Pelvic-fin length & 15.6 & 32 & 13.3 & 15.5 & 1.0 \\
\hline Pelvic-fin origin to anal-fin origin & 18.0 & 32 & $14.7-18.7$ & 16.4 & 1.1 \\
\hline Dorsal-fin length males & 34.4 & 20 & $30.2-39.7$ & 33.1 & 2.7 \\
\hline Dorsal-fin length females & - & 14 & $24.7-31.3$ & 28.0 & 2.0 \\
\hline Dorsal-fin base length & 15.6 & 32 & $12.4-16.5$ & 14.0 & 0.9 \\
\hline Anal-fin length males & 26.6 & 20 & $22.5-34.6$ & 26.4 & 3.1 \\
\hline Anal-fin length females & - & 14 & $19.0-23.0$ & 20.8 & 1.5 \\
\hline Anal-fin base length & 28.7 & 36 & $23.5-29.8$ & 26.3 & 1.6 \\
\hline Eye to dorsal-fin origin & 40.6 & 32 & $37.6-42.9$ & 41.0 & 1.1 \\
\hline Dorsal-fin origin to caudal-fin base & 49.2 & 32 & $47.6-51.9$ & 49.5 & 1.1 \\
\hline Head depth & 25.8 & 32 & $23.3-28.2$ & 26.0 & 1.1 \\
\hline Head length & 25.4 & 32 & $23.2-26.7$ & 25.1 & 0.9 \\
\hline \multicolumn{6}{|l|}{ Percents of HL } \\
\hline Horizontal eye diameter & 41.9 & 32 & $41.9-47.3$ & 44.8 & 1.8 \\
\hline Snout length & 25.8 & 32 & $23.0-26.8$ & 24.7 & 1.2 \\
\hline Interorbital width & 35.5 & 32 & $32.7-38.2$ & 35.8 & 1.3 \\
\hline Upper jaw length & 41.9 & 32 & $40.0-46.4$ & 42.1 & 1.4 \\
\hline
\end{tabular}


arthropods. One specimen (MZUSP 114029) has a parasitc Isopoda attached to the inside its urogenital cavity.

\section{Discussion}

Hyphessobrycon diastatos is readily diagnosed from most congeners by the absence of humeral spot. In addition to the species mentioned in the diagnosis, three other species currently in Hyphessobrycon also lack a humeral spot, $H$. arianae Uj \& Géry, H. iheringi Fowler, and H. latus Fowler. Hyphessobrycon latus is assigned as species inquirendae in Characidae (Reis et al., 2003) and H. arianae and H. iheringi are considered valid species (Lima et al., 2003). Hyphessobrycon arianae is prossibly junior synonym of Cheirodon stenodon Eigenmann (Malabarba, 1998) and the holotypes of $H$. iheringi and $H$. latus belong to the subfamily Cheirodontinae (H. A. Britski, pers. comm.; Carvalho, 2011), and thus these species are not representatives of Hyphessobrycon.

The absence of an adipose fin is uncommon within the Characiformes, and has evolved independently in different lineages of the Characidae (Mirande, 2010). Some such cases are possibly related with miniaturization events (Weitzman \& Malabarba, 1999; Bührnheim et al., 2008). Despite the realization that reductive characters are unlikely to be useful in studies of phylogenetic relationships of characids, given their homoplastic nature (Weitzman \& Fink, 1983), the absence or presence of an adipose fin remains in wide use as a criterion to separate genera in the family. The new species has a variably developed adipose fin (Fig. 6). Of 294 specimens examined, only one completely lacks the fin. The genus Hasemania Ellis was originally defined as "like a Hyphessobrycon, but without an adipose" (Ellis, 1911). Curiously, Hyphessobrycon taurocephalus, described in the same paper and also lacking an adipose fin, was not included in Hasemania. Intraspecific variation of this character within the genus was reported for Hyphessobrycon negodagua (adipose fin present in four specimens, absent in 158 according to Lima \& Gerhard, 2001), H. eilyos (present in 163 specimens, absent in 52 according to Lima \& Moreira, 2003), H. uaiso Carvalho \& Langeani (adipose fin variably developed in 512 specimens, absent in 1 specimen, according to Carvalho \& Langeani, 2013) and H. langeanii Lima \& Moreira (adipose fin always present but vestigial in some specimens according to Lima \& Moreira, 2003). Such intraspecific variation of adipose fin was also observed by Géry (1977) in Hasemania nana (Lütken) and by the present authors (present in 3, absent in 173 specimens; MZUSP 38040). These observations show that generic limits between Hyphessobrycon and Hasemania, so far based only on the differential presence or absence of adipose fin, should be reevaluated. In view of that, a comparison of Hyphessobrycon diastatos with all Hasemania species is in order. Regardless of the presence or absence of an adipose fin, Hyphessobrycon diastatos differs from all Hasemania species, except $H$. hanseni (Fowler), H. maxillaris Ellis, $H$. melanura Ellis, $H$. nambiquara Bertaco \& Malabarba, and $H$. nana by having
15-18 branched anal-fin rays (vs. 10-14). It can be distinguished from H. hanseni, H. melanura, H. nambiquara, and $H$. nana by the well-defined round caudal-peduncle spot (vs. triangular shape caudal-spot in $H$. melanura, spread

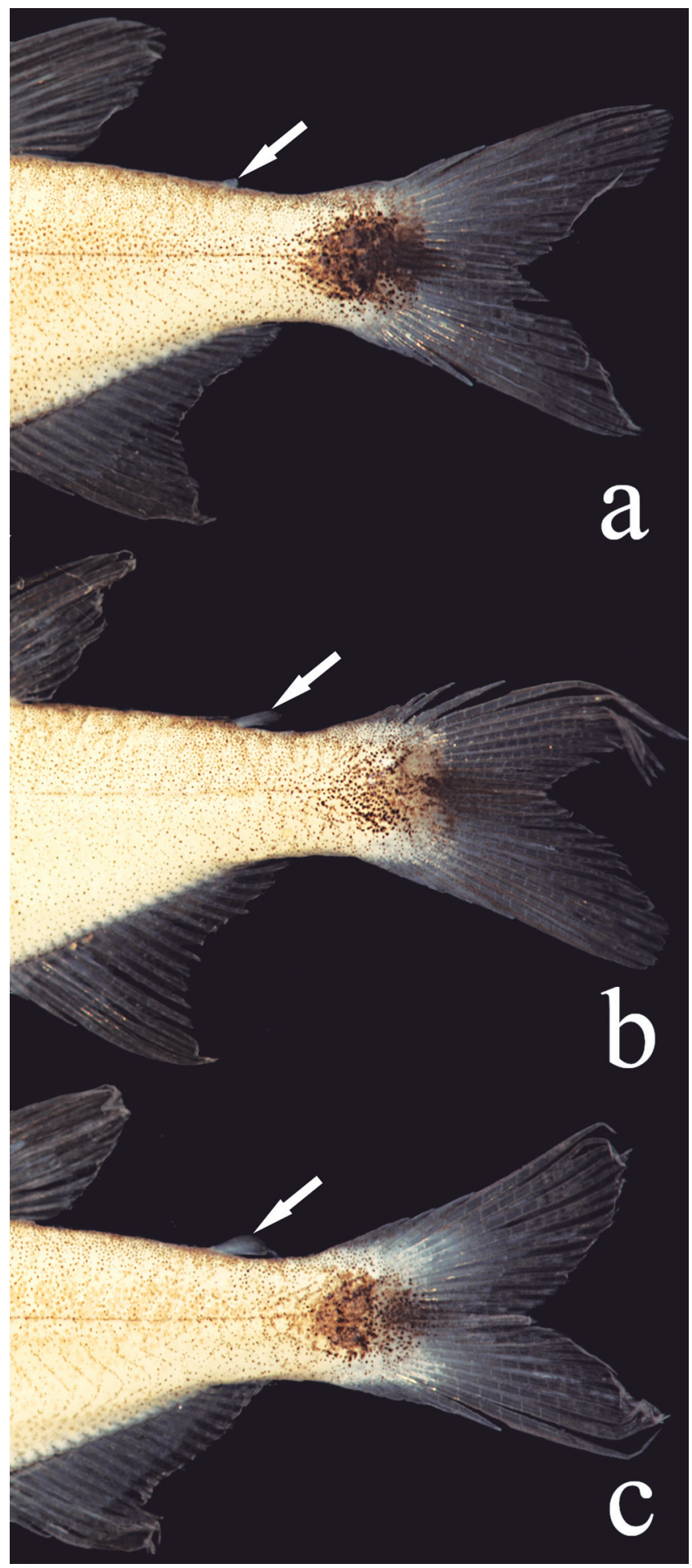

Fig. 6. Adipose fin variation in Hyphessobrycon diastatos, paratypes, all from MZUSP 114029, (a) $20.1 \mathrm{~mm}$ SL, (b) 19.4 $\mathrm{mm} \mathrm{SL}$, and (c) $18.1 \mathrm{~mm} \mathrm{SL}$. Arrows indicate the position of the adipose fin. 
caudal-peduncle blotch with inconspicuous border in $H$. hanseni and $H$. nana and as a prolongation of the midlateral band in $H$. nambiquara). Finally, it is distinguished from $H$. maxillaris by a well-defined black round spot extending from posterior half of caudal peduncle to middle caudal-fin rays (vs. faint caudal spot, not continued with the caudal-fin rays).

Species of Hemigrammus lacking humeral spot are: Hemigrammus boesemani Géry, H. brevis Ellis, H. diagonicus Mendonça \& Wosiacki, $H$. filamentosus Zarske, $H$. hyanuary Durbin, H. levis Durbin, H. mahnerti Uj \& Géry, H. marginatus Ellis, H. matei Eigenmann, H. micropterus (Eigenmann), $H$. parana Marinho, Carvalho, Langeani \& Tatsumi, $H$. rhodostomus Ahl, $H$. rodwayi Durbin, $H$. silimoni Britski \& Lima, and $H$. tridens Eigenmann. Besides the absence of scales covering the caudal-fin lobes, the new species can be diagnosed by all aforementioned species, except $H$. levis, $H$. mahnerti, $H$. rodwayi, $H$. silimoni, and $H$. tridens by having 15-18 branched anal-fin rays (vs. 14 or less in H. hyanuary and $H$. rhodostomus, 19 or more in remaining species); from $H$. rodwayi, $H$. silimoni, $H$. levis, and $H$. tridens by 6 branched pelvic-fin rays ( $v s .7$ ), and from $H$. mahnerti by the absence of a narrow line above anal-fin base ( $v s$. presence). In addition to the species mentioned above, two other species assigned as incertae sedis in Characidae by Reis et al. (2003) and currently allocated in Cheirodon Girard (C. jaguaribensis Fowler and $C$. macropterus Fowler), seem to be, in fact, species of Hemigrammus lacking humeral spot (H. A. Britski, pers. comm.; Malabarba, 1994). Hyphessobrycon diastatos is distinguished from these species by having 15-18 (mode: 16) branched analfin rays (vs. 17-22, mode: 19 ) and absence of sexually dimorphic elongation of pelvic fin in males (vs. presence).

Zanata \& Camelier (2010) proposed a putative close relationship among Hyphessobrycon brumado, H. negodagua, and $H$. parvellus on the basis mainly of a reduced muscle layer between the first and second ribs, the absence of humeral spot, and the sexually dimorphic caudal spot. Males of the aforementioned species have a poorly-defined caudalpeduncle, formed by pigmentation spread over inner portions of the caudal lobes (especially in $H$. negodagua and $H$. parvellus, Fig. 7). Respective females have a round and relatively well-defined caudal-peduncle blotch, not extending to the caudal-fin lobes. Hyphessobrycon diastatos shares these characters, except that its caudal-peduncle blotch is round,

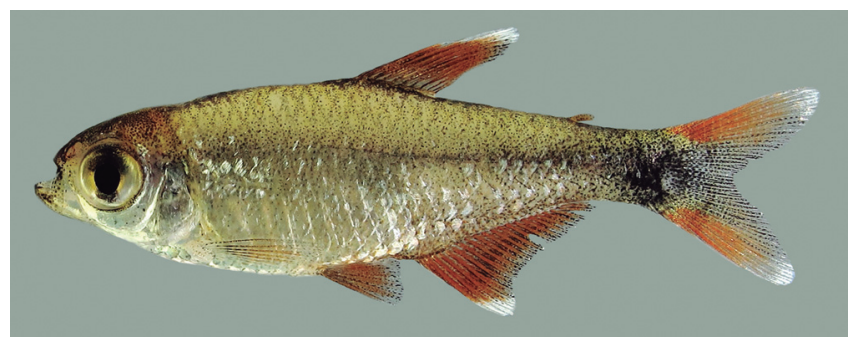

Fig. 7. Hyphessobrycon parvellus, MZUSP 111234, male, 19.3 mm SL, Brazil, Bahia, rio Jequiriçá basin. relatively well-defined, and does not extend to the caudal-fin lobes in either sex. Whether those species compose a monophyletic assemblage still requires independent confirmation. All aforementioned species are from Northeastern Brazilian coastal drainages, while $H$. diastatos is founded in both the rio São Francisco and rio Tocantins basins.

The rio São Francisco basin has part of its ichthyofauna shared with neighboring river systems. Lima \& Caires (2011) provided numerous examples of fishes shared between the rio São Francisco and the upper rio Paraná basin (e.g., Piabina argentea Reinhardt (cf. Vari \& Harold, 2001); Salminus hilarii Valenciennes (cf. Lima, 2006); Corydoras difluviatilis Britto \& Castro (cf. Britto \& Castro, 2002)) and with eastern coastal drainages (e.g., Pareiorhaphis Miranda Ribeiro (cf. Pereira \& Reis, 2002); Neoplecostomus Eigenmann \& Eigenmann (cf. Langeani, 1990); Steindachnerina elegans (Steindachner) (cf. Vari, 1988)). Contrastingly, there are few examples of fish species distributed in both the rio São Francisco and rio Tocantins basins. In addition to Hyphessobrycon diastatos, other such cases are Astyanax novae Eigenmann (cf. Garutti \& Venere, 2009), Cichlasoma sanctifranciscense Kullander (cf. Lima \& Caires, 2011), and some clades of Cynolebias Steindachner and Hypsolebias Costa (cf. Costa, 2010). The hydrogeographic divide between the São Francisco and Tocantins basins is the Serra Geral de Goiás, a Cretaceous sedimentary plateau overlying the Precambrian São Francisco craton (Villela \& Nogueira, 2011; Bartorelli, 2013). Therefore, the hypothesis that the same ancestral species were once widely distributed across both basins before the formation of the Serra Geral de Goiás is rejected. More recent events between these watersheds must explain the distribution pattern of the species.

The presence of Hyphessobrycon diastatos in both middle rio São Francisco (rio Grande basin) and middle rio Tocantins (rio do Sono basin) may be a result of the common headwater ("água emendada") between the rio Sapão (rio São Francisco basin) and the rio Galheiros (rio Tocantins basin), which potentially allow current faunistic interchange (Lima \& Caires, 2011). The presence of the species in both the middle rio São Francisco (rio Grande basin) and the upper rio Tocantins (rio São Domingos basin) have two alternative explanations. The distribution can be a result of the dispersal of the species from the middle to upper rio Tocantins, although this hypothesis seems to be less parsimonious. Another explanation is a putative headwater capture of a stretch of a stream from the rio São Francisco basin into the rio Tocantins. Geological evidence shows that the western border of the Serra Geral de Goiás plateau has been gradually eroded (Lima \& Caires, 2011) and could potentially promote headwater capture events of the rio São Francisco basin by the rio Tocantins basin. The presence of Cichlasoma sanctifranciscense, a species widely distributed in the rio São Francisco basin, also in the rio São Domingos basin (upper rio Tocantins; MZUSP 114033) provides further evidence of such hypothesis. 
Stream capture occurs when part or all of a river flow is diverted to a neighboring drainage system, as a result of unequal rates of erosion or relative tectonic movements (Bishop, 1995; Wilkinson et al., 2006). As a consequence, the area upstream of the diversion drains to a new watershed and is then separated from its original watershed. Such captures potentially represent simultaneous vicariant and geodispersal events for the aquatic fauna. Headwater stream capture has been suggested as one of the main sources of vicariant events and, consequently, one main causes of diversification in the South American continent (cf. Ribeiro et al., 2006). Therefore, headwater captures enrich the ichthyofaunal composition, providing mix of previously isolated faunas of either side of a watershed divide. Some basins indeed present a mosaic of fish assemblages composed of elements from different origins recruited across different times and events (Hubert \& Renno, 2006; Lima \& Ribeiro, 2011). Cleary, this is the case of the rio São Domingos basin, which has a mixed ichthyofauna composed of typically Amazonian groups (e.g., Creagrutus spp. and Retroculus spp.) along with other taxa originally from the rio São Francisco basin (e.g., Cichlasoma sanctifranciscense and Hyphessobrycon diastatos).

Comparative material. Paratypes of Hasemania crenuchoides Zarske \& Géry, 1999: ZMB 32959, 5, 35.1-40.7 mm SL, Brazil, Goiás, upper rio São Bartolomeu. Paratypes of Hasemania kalunga Bertaco \& Carvalho, 2010: MZUSP 104303, 12, 20.8-43.4 mm SL, Brazil, Goiás, upper rio Tocantins basin. Hasemania hanseni: MZUSP 40835, 70, 12.7-25.7 mm SL, Brazil, Tocantins, rio Tocantins basin. Syntypes of Tetragonopterus nanus (= Hasemania nana) (Lütken 1875): ZMB 92202, 4, 15.0-18.3 mm SL, Brazil, Minas Gerais, Lagoa Santa. MZUSP 38040, 173, 15.6-23.6 mm SL, Minas Gerais, rio São Francisco basin. Holotype of Hasemania piatan Zanata \& Serra, 2010: MZUSP 104538, 54.0 mm SL; UFBA 4298, paratypes, 20, 3 c\&s 25.8-29.7 mm SL, 22.4-41.4 mm SL, Brazil, Bahia, rio de Contas basin. Hemigrammus boesemani: MZUSP 65445, 20 of 67, 3 c\&s 24.7-26.0 mm SL, 22.0-26.1 mm SL, Suriname, Paramaribo, rio Suriname basin. Hemigrammus brevis: MCP 17068, 12 of 150, 2 c\&s 21.8-22.5 mm SL, 13.0-22.0 mm SL, Brazil, Bahia, São Francisco. Hemigrammus hyanuary: MZUSP 42348, 8, 1 c\&s 22.4 mm SL, 17.4-22.7 mm SL, Brazil, Amazonas, rio Solimões. Syntypes of Hemigrammus levis Durbin, 1908: MCZ 20738, 5, 32.6-37.2 mm SL, Brazil, Amazonas, rio Amazonas basin; MZUSP 85686, 797, 15.5-29.5 mm SL, Amazonas, rio Negro basin. Hemigrammus marginatus: UFBA 3568, 213, 20.9-30.6 mm SL, Brazil, Bahia, rio Itapicuru basin. Hemigrammus rhodostomus: MZUSP 29435, 6701, 25.3-33.2 mm SL, Brazil, Amazonas, rio Negro. Hemigrammus rodwayi: MZUSP 65436, 10 of 23, 2 c\&s 19.1-26.2 mm SL, 18.8-26.9 mm SL, Suriname, Paramaribo, rio Suriname basin. Hyphessobrycon bifasciatus: UFBA 4971, 19, 16.333.4 mm SL, Brazil, Bahia, rio Jucuruçu basin. Holotype of Hyphessobrycon brumado Zanata \& Camelier, 2010: MZUSP 101246, 30.7 mm SL; MZUSP 105730, paratypes, 5, 26.2-30.4 mm SL; UFBA 4340, 13, 1 c\&s 24.6 mm SL, 25.1-26.9 mm SL; UFBA 4341, paratypes, 22, 2 c\&s 25.6-28.4 mm SL, 25.1-31.6 mm SL, Brazil, Bahia, rio de Contas basin. Holotype of Hyphessobrycon eilyos Lima \& Moreira, 2003: MZUSP 75126, 22.3 mm SL; MZUSP 73344, paratypes, 11, 15.0-23.3 mm SL, Brazil, Mato Grosso, upper rio
Araguaia basin. Paratypes of Hyphessobrycon guarani Mahnert \& Géry, 1987: MZUSP 38399, 3, 25.2-30.6 mm SL, Paraguay, upper rio Paraná basin. Hyphessobrycon itaparicensis: UFBA 2687, 3, 28.832.7 mm SL, Brazil, Bahia, Ilha de Itaparica. Hyphessobrycon micropterus: UFBA 2843, 23.5 mm SL, Brazil, Bahia, rio Itapicuru basin. Holotype of Hyphessobrycon negodagua Lima \& Gerhard, 2001: MZUSP 53898, 26.7 mm SL; MZUSP 54589, paratypes, 103, 19.6-29.2 mm SL; UFBA 4301, 9, 16.5-19.7 mm SL; UFBA 5392, 26, 18.1-29.5 mm SL, Brazil, Bahia, rio Paraguaçu basin. Hyphessobrycon parvellus: UFBA 4081, 63, 12.5-21.7 mm SL, Brazil, Bahia, rio Itapicuru basin; UFBA 4302, 118, 7.1-19.2 mm SL, Bahia, rio Açu basin; UFBA 4308, 62, 15.6-19.6 mm SL, Bahia, rio Real basin; UFBA 4309, 60, 10, 10.3-20.2 mm SL, Bahia, rio Pojuca basin; UFBA 4317, 74, 13.8-24.2 mm SL, Bahia, rio Paraguaçu basin; UFBA 4320, 3, 18.8-20.2 mm SL, Bahia, rio de Contas basin. Paratypes of Hyphessobrycon procerus Mahnert \& Géry, 1987: MZUSP 38400, 2, 24.0-27.9 mm SL, Paraguay, rio Guyrau-gua basin. Paratypes of Hyphessobrycon taurocephalus Ellis, 1911: FMNH 54390, 23, 30.1-42.5 mm SL, Brazil, Paraná, rio Iguaçu basin. Paratypes of Hyphessobrycon vinaceus Bertaco, Malabarba \& Dergam, 2007: MZUSP 94439, 3, 48.3-56.9 mm SL, Brazil, Minas Gerais, rio Pardo basin.

\section{Acknowledgments}

The paper was benefitted from the comments of Fernando Carvalho (UNESP/IBILCE) and Mario de Pinna (MZUSP). Fernando Carvalho provided counts from paratypes of Hasemania hanseni and Heraldo Britski (MZUSP) provided meristic and morphometric data from the holotypes of Cheirodon jaguaribensis, C. macropterus, Hyphessobrycon iheringii, H. latus, and $H$. piabinhas. We are grateful to José L. Birindelli (UEL) for Figs. 3 and 7. Luciana Martins (MZUSP) helped us with the Fig. 2. We thank also Caio Santos, José L. Birindelli, and Marina V. Loeb for help in the field. Most specimens were collected during an expedition funded by the South American Characiformes Inventory (FAPESP 2011/ 50282-7, http://www.projeto-saci.com). Authors were funded by FAPESP (2011/23419-1, FCPD; 2009/15075-0, MMFM, and 2012/00840-6, PC).

\section{Literature Cited}

Bartorelli, A. 2013. Contexto geológico e evolução da rede hidrográfica do Brasil. Pp. 574-610. In: Hasui, Y., C. D. Carneiro, F. F. M. Almeida \& A. Bartorelli (Eds.). Geologia do Brasil. Editora Beca, São Paulo.

Bishop, P. 1995. Drainage rearrangement by river capture, beheading and diversion. Progress in Physical Geography, 19: 449-473.

Britto, M. R. \& R. M. C. Castro. 2002. New corydoradine catfish (Siluriformes: Callichthyidae) from the upper Paraná and São Francisco: the sister group of Brochis and most of Corydoras species. Copeia, 2002: 1006-1015.

Bührnheim, C. M., T. P. Carvalho, L. R. Malabarba \& S. H. Weitzman. 2008. A new genus and species of characid fish from the Amazon basin - the recognition of a relictual lineage of characid fishes (Ostariophysi: Cheirodontinae: Cheirodontini). Neotropical Ichthyology, 6: 663-678. 
Carvalho, F. R. 2011 Sistemática de Hyphessobrycon Durbin, 1908 (Ostariophysi: Characidae). Unpublished Ph.D. Dissertation, Universidade Federal do Rio Grande do Sul, Porto Alegre, 340p.

Carvalho, F. R. \& F. Langeani. 2013. Hyphessobrycon uaiso: new characid fish from the rio Grande, upper rio Paraná basin, Minas Gerais State (Ostariophysi: Characidae), with a brief comment about some types of Hyphessobrycon. Neotropical Ichthyology, 11: 525-536.

Costa, W. J. E. M. 2010. Historical biogeography of cynolebiasine annual killifishes inferred from dispersal-vicariance analysis. Journal of Biogeography, 2010: 98-110.

Eigenmann, C. H. 1908. Preliminary descriptions of new genera and species of tetragonopterid characins. (Zoölogical Results of the Thayer Brazilian expedition). Bulletin of the Museum of Comparative Zoology, 52: 91-106.

Eigenmann, C. H. 1917. The American Characidae. Memoirs of the Museum of Comparative Zoology, 43: 1-102.

Ellis, M. D. 1911. On the species of Hasemania, Hyphessobrycon, and Hemigrammus collected by J. D. Haseman for the Carnegie Museum. Annals of the Carnegie Museum, 8: 148-163.

Fink, W. L. \& S. H. Weitzman. 1974. The so-called cheirodontin fishes of Central America with description of two new species (Pisces, Characidae). Smithsonian Contributions to Zoology, 172: 1-46.

García-Alzate, C. A., C. Román-Valencia \& D. C. Taphorn. 2013a. Una nueva especie de Hyphessobrycon (Characiformes: Characidae) de la cuenca del río Telembí, vertiente sur del Pacífico, Colombia. Revista de Biologia Tropical, 61: 181-192.

García-Alzate, C. A., C. Román-Valencia \& H. Ortega. 2013b. Hyphessobrycon taphorni y H. eschwartzae (Teleostei: Characidae) dos nuevas especies de peces de la cuenca del río Madre de Dios, Perú. Revista de Biologia Tropical, 61: 859-873.

Garutti, V. \& P. C. Venere. 2009. Astyanax xavante, a new species of characid from middle rio Araguaia in the Cerrado region, Central Brazil (Characiformes: Characidae). Neotropical Ichthyology, 7: 377-383.

Géry, J. 1966. Hyphessobrycon vilmae sp. nov., a new tetra from the upper Juruena, Brazil, with keys to the heterorhabdus-like species. Ichthyologica, the Aquarium Journal, 37: 63-70.

Géry, J. 1977. Characoids of the world. T. F. H. Publications, New Jersey, Neptune City.

Hubert, N. \& J.-F. Renno. 2006. Historical biogeography of South American freshwater fishes. Journal of Biogeography, 33: 14141436.

Ingenito, L. F. S., F. C. T. Lima \& P. A. Buckup. 2013. A new species of Hyphessobrycon Durbin (Characiformes: Characidae) form the rio Juruena basin, central Brazil, with notes on $H$. loweae Costa \& Géry. Neotropical Ichthyology, 11: 33-44.

Javonillo, R., L. R. Malabarba, S. H. Weitzman \& J. R. Burns. 2010. Relationships among major lineages of characid fishes (Teleostei: Ostariophysi: Characiformes), based on molecular sequence data. Molecular Phylogenetics and Evolution, 54: 498-511.

Langeani, F. 1990. Revisão do gênero Neoplecostomus, com a descrição de quatro espécies novas do sudeste brasileiro (Ostariophysi, Siluriformes, Loricariidae). Comunicações do Museu de Ciências da PUCRS, 3: 3-31.

Lima, F. C. T. 2006. Revisão taxonômica e relações filogenéticas do gênero Salminus (Teleostei: Ostariophysi: Characiformes: Characidae). Unpublished Ph.D. Dissertation, Universidade de São Paulo, São Paulo, 253p.
Lima, F. C. T. \& R. A. Caires. 2011. Peixes da Estação Ecológica Serra Geral do Tocantins, bacias dos rios Tocantins e São Francisco, com observações sobre as implicações biogeográficas das “águas emendadas” dos rios Sapão e Galheiros. Biota Neotropica, 11: 1-20.

Lima, F. C. T. \& P. Gerhard. 2001. A new Hyphessobrycon (Characiformes: Characidae) from Chapada Diamantina, Bahia, Brazil, with notes on its natural history. Ichthyological Exploration of Freshwaters, 12: 105-114.

Lima, F. C. T., L. R. Malabarba, P. A. Buckup, J. F. P. Silva, R. P. Vari, A. Harold, R. C. Benine, O. Oyakawa, C. S. Pavanelli, N. A. Menezes, C. A. S. Lucena, M. C. S. L. Malabarba, Z. M. S. Lucena, R. E. Reis, F. Langeani, L. Casatti, V. A. Bertaco, C. Moreira \& P. H. F. Lucinda. 2003. Genera incertae sedis in Characidae. Pp. 106-169. In: Reis, R. E., S. O. Kullander \& C. J. Ferraris Jr (Eds.). Check List of Freshwater Fishes of South and Central America. Porto Alegre, Edipucrs.

Lima, F. C. T. \& C. R. Moreira. 2003. Three new species of Hyphessobrycon (Characiformes: Characidae) from the upper rio Araguaia basin in Brazil. Neotropical Ichthyology, 1: 21-33.

Lima, F. C. T. \& A. C. Ribeiro. 2011. Continental-scale tectonic controls of biogeography and ecology. Pp. 145-164. In: Albert, J. S. \& R. E. Reis (Eds.). Historical biogeography of Neotropical freshwater fishes. Berkeley, University of California Press.

Malabarba, L. R. 1994. Sistemática e Filogenia de Cheirodontinae (Ostariophysi: Characiformes: Characidae). Unpublished Ph.D. Dissertation, Universidade de São Paulo, São Paulo, 287p.

Malabarba, L. R. 1998. Monophyly of the Cheirodontinae, characters and major clades (Ostariophysi, Characidae). Pp. 193-234. In: Malabarba, L. R., R. E. Reis, R. P. Vari, Z. M. S. Lucena \& C. A. S. Lucena (Eds.). Phylogeny and classification of Neotropical fishes, Edipucrs, Porto Alegre.

Malabarba, L. R., V. A. Bertaco, F. R. Carvalho \& T. O. Litz. 2012. Revalidation of the genus Ectrepopterus Fowler (Teleostei: Characiformes), with the redescription of its type species, $E$. uruguayensis. Zootaxa, 3204: 47-60.

Mirande, J. M. 2009. Weighted parsimony phylogeny of the family Characidae (Teleostei: Characiformes). Cladistics, 2009: 573-613.

Mirande, J. M. 2010. Phylogeny of the family Characidae (Teleostei: Characiformes) from characters to taxonomy. Neotropical Ichthyology, 9: 385-568.

Oliveira, C., G. S. Avelino, K. T. Abe, T. C. Mariguela, R. C. Benine, G. Orti, R. P. Vari \& R. M. C. Castro. 2011. Phylogenetic relationships within the speciose family Characidae (Teleostei: Ostariophysi: Characiformes) based on multilocus analysis and extensive ingroup sampling. BMC Evolutionary Biology, 11: 1-25.

Pereira, E. H. L. \& R. E. Reis. 2002. Revision of the loricariid genera Hemipsilichthys and Isbrueckerichhtys (Teleostei: Siluriformes), with descriptions of five new species of Hemipsilichthys. Ichthyological Exploration of Freshwaters, 13: 97-146.

Reis, R. E., S. O. Kullander \& C. J. Ferraris, Jr. (Eds.). 2003. Check list of the freshwater fishes of South and Central America. Edipucrs, Porto Alegre.

Ribeiro, A. C., F. C. T. Lima, C. Riccomini \& N. A. Menezes. 2006. Fishes of the Atlantic Rainforest of Boracéia: Testimonies of the Quaternary fault reactivation within a Neoproterozoic tectonic province in Southeastern Brazil. Ichthyological Exploration of Freshwaters, 17: 157-164.

Ribeiro, M. C. L. B., M. Petrere Jr. \& A. A. Juras. 1995. Ecological integrity and fisheries ecology of the Araguaia-Tocantins river 
basin, Brazil. Regulated rivers: Research \& Management, 11: 325-350.

Taylor, W. R. \& G. C. Van Dyke. 1985. Revised procedures for staining and clearing small fishes and other vertebrates for bone and cartilage study. Cybium, 9: 107-119.

Vari, R. P. 1988. The Curimatidae, a lowland Neotropical fish family (Pisces: Characiformes); distribution, endemism, and phylogenetic biogeography. Pp. 343-377. In: Proceedings of a Workshop on Neotropical Distribution Patterns. Vanzolini, P. E. \& W. R. Heyer (Eds.). Academia Brasileira de Ciências, Rio de Janeiro.

Vari, R. P. \& A. S. Harold. 2001. Phylogenetic study of the neotropical fish genera Creagrutus Günther and Piabina Reinhardt (Teleostei: Ostariophysi: Characiformes), with revision of the Cis-Andean species. Smithsonian Contributions to Zoology, 613: 1-239.

Villela, F. N. J. \& C. Nogueira. 2011. Geology and geomorphology of Serra Geral do Tocantins Ecological Station. Biota Neotropica, 11: 217-230.

Weitzman, S. H. \& W. L. Fink. 1983. Relationships of the neon tetras, a group of South American freshwater fishes (Teleostei, Characidae), with comments on the phylogeny of New World Characiformes. Bulletin of the Museum of Comparative Zoology, 150: 339-395.
Weitzman, S. H. \& L. R. Malabarba. 1999. Systematics of Spintherobolus (Teleostei: Characidae: Cheirodontinae) from Eastern Brazil. Ichthyological Exploration of Freshwaters, 10: $1-43$.

Weitzman, S. H. \& L. Palmer. 1997. A new species of Hyphessobrycon (Teleostei: Characidae) from the Neblina region of Venezuela and Brazil, with comments on the putative "rosy tetra clade”. Ichthyological Exploration of Freshwaters, 7: 209242.

Wilkinson, M. J., L. G. Marshall \& J. G. Lundberg. 2006. River behavior on megafans and potential influences on diversification and distribution of aquatic organisms. Journal of South American Earth Sciences, 21: 151-172.

Zanata, A. M. \& P. Camelier. 2010. Hyphessobrycon brumado: a new characid fish (Ostariophysi: Characiformes) from the upper rio de Contas drainage, Chapada Diamantina, Bahia, Brazil. Neotropical Ichthyology, 8: 771-777.

Submitted October 4, 2013 Accepted April 16, 2014 by Luiz R. Malabarba

Published June 30, 2014 